\title{
PENGARUH STRUKTUR MODAL TERHADAP RASIO HASIL PENGEMBALIAN ATAS EKUITAS (ROE) PADA PERUSAHAAN PROPERTY DAN REAL ESTATE YANG TERDAFTAR DI BEI PERIODE TAHUN 2015 - 2017
}

\author{
Yudi Pratama Putra ${ }^{1}$, Ummul Khair ${ }^{2}$, Yunita Lestari ${ }^{3}$ \\ ${ }^{123}$ Fakultas Ekonomi dan Bisnis Universitas Muhammadiyah Bengkulu \\ Email:
}

\begin{abstract}
ABSTRAK
Struktur modal sangat dibutuhkan dalam sebuah perusahaan supaya dapat mencapai tujuan jangka panjangnya, oleh karena itu dibutuhkan pemilihan sumber pendanaan yang tepat untuk pengoptimalan struktur modal perusahaan. Sebagian dari perusahaan property dan real estate yang ada di BEI terus mengalami penurunan laporan keuangan (laba bersih) pada periode tahun 2015 - 2017. Hal tersebut diduga karena pengolahan struktur modal yang kurang optimal pada setiap perusahaan. Penelitian ini bertujuan untuk mengetahui Pengaruh Struktur Modal Terhadap Rasio Hasil Pengembalian Atas Ekuitas (ROE) Pada Perusahaan Property Dan Real Estate Yang Terdaftar Di BEI Periode Tahun 2015 - 2017. Penelitian ini menggunakan metode kuantitatif, dengan menggunakan data sekunder melalui dokumentasi. Objek dalam penelitian ini adalah perusahaan Property dan Real Estate Yang Terdaftar Di BEI Periode Tahun 2015 2017. Metode penarikan sampel menggunakan purposive sampling, jumlah sampel dalam penelitian ini adalah sebanyak 41 perusahaan. Metode analisis data yang digunakan adalah analisis regresi linier berganda. Hasil penelitian ini menunjukkan bahwa rasio utang atas asset tidak berpengaruh signifikan terhadap rasio hasil pengembalian atas ekuitas (ROE). Rasio utang atas ekuitas tidak berpengaruh signifikan terhadap rasio hasil pengembalian atas ekuitas (ROE). Rasio utang jangka panjang atas ekuitas tidak berpengaruh terhadap rasio hasil pengembalian atas ekuitas (ROE). Rasio waktu bunga yang diperoleh berpengaruh signifikan terhadap rasio hasil pengembalian atas ekuitas (ROE). Secara simultan struktur modal yang diwakili rasio utang atas asset, rasio utang atas ekuitas, rasio utang jangka panjang atas ekuitas, rasio waktu bunga yang diperoleh berpengaruh signifikan terhadap rasio hasil pengembalian atas ekuitas (ROE) sebesar 23,0\% dan selebihnya sebesar $77 \%$ dipengaruhi oleh faktor - faktor lain yang tidak dimasukkan dalam penelitian ini.
\end{abstract}

Kata Kunci: $\quad$ Struktur Modal, $R O E$

\section{ABSTRACT}

Capital structure is needed in a company in order to achieve its long-term goals. Therefore, this must take the appropriate selection to optimalize the capital structure of company. This was as seen from Property and Real Estate companies as listed in BEI, which always decreased the financial statements of the period 2015-2017. It is suspected due to the less optimal of capital structure as a result the decrease performance of the companies. This research aims to determine the influence of capital structure on retrun on equity (roe) on Property and Real Estate company performance listed in BEI during 2015-2017. This research used quantitative method by using secondary data through documentation. The objects of this research are Property and Real Estate companies listed on the BEI. The sample was purposive sampling from 41 companies. The data analysis methods used multiple linear regression analyses. The results of this study showed that the debt and equity ratio to assets have no significant effect on the equity return ratio. The longterm debt to equity ratio has no effect on the return on equity ratio. The interest rate ratio found significant effect on the return on equity ratio. Simultaneously, the capital structure represented the debt ratio to asset, and equity, for long-term debt was equity ratio, while the interest rate ratio showed significantly to the return on equity ratio, as shown from equity result $23.0 \%$ and its residual rest $77 \%$ which influenced by other factors not included in this study.

Keywords: capital structure, $R O E$ 


\section{PENDAHULUAN}

Struktur modal sangat dibutuhkan dalam sebuah perusahaan supaya perusahaan dapat mencapai tujuan jangka panjangnya, struktur modal juga penting untuk perkembangan serta daya tahan perusahaan, oleh karena itu dibutuhkan pemilihan sumber pendanaan yang tepat untuk pengoptimalan struktur modal perusahaan. Struktur modal yang optimal akan memaksimalkan laba yang diperoleh perusahaan serta mempertahankan kemampuan perusahaan dalam menghadapi persaingan dengan perusahaan lain, sedangkan struktur modal yang kurang optimal dapat berakibat pada penurunan rasio hasil pengembalian atas ekuitas (ROE) perusahaan dan memungkinkan tingginya risiko kegagalan bisnis perusahaan tersebut. Pemahaman suatu perusahaan mengenai struktur modal dapat membantu perusahaan tersebut dalam mengalokasikan modal secara maksimal dengan tujuan agar rasio hasil pengembalian atas ekuitas (ROE) menjadi maksimal. Rasio hasil pengembalian atas ekuitas (ROE) adalah rasio yang digunakan untuk mengukur kemampuan perusahaan untuk menghasilkan laba dari investasi pemegang saham di perusahaan tersebut, dengan kata lain rasio ini menunjukkan seberapa banyak keuntungan yang dapat dihasilkan oleh perusahaan dari setiap rupiah yang diinvestasikan oleh para pemegang saham (Kasmir, 2010: 115). Sejalan dengan penelitian (Yusmaniarti, Hesti, \& Lola, 2019), yang menunjukan bahwa Profitabilitas tidak berpengaruh terhadap nilai perusahan. Dan Leverage berpengaruh terhadap nilai perusahaan. Selanjutnya dijelaskan bahwa profitabilitas digunkan untuk mengukur kinerja perusahaan yang akan mempengaruhi nilai perusahaan.

Penelitian Kristina dan Leny (2015) menganai struktur modal yang menguji pengaruh struktur modal terhadap 14 perusahaan industri barang konsumsi yang terdaftar di Bursa Efek Indonesia, menemukan bahwa secara simultan rasio utang atas asset (DAR), rasio utang atas ekuitas (DER), rasio utang jangka panjang atas ekuitas (LDER) dan rasio waktu bunga yang diperoleh (TIER) mempunyai pengaruh yang signifikan terhadap kinerja keuangan yang diwakili rasio hasil pengembalian atas ekuitas (ROE) pada perusahaan sektor industry barang konsumsi yang terdaftar di Bursa Efek Indonesia tahun 2009 - 2013. Secara parsial (DR) tidak memiliki pengaruh terhadap kinerja keuangan yang diwakili oleh (ROE) dengan arah koefisien negatif, (DER) tidak memiliki pengaruh terhadap kinerja keuangan yang diwakili oleh (ROE) dengan arah koefisien positif, sedangkan (LDER) memiliki pengaruh signifikan terhadap kinerja keuangan yang diwakili (ROE) dengan arah koefisien negatif, (TIER) memiliki pengaruh signifikan terhadap kinerja keuangan yang diwakili (ROE) dengan arah koefisien positif.

Penelitian Irmadelia, dkk (2014) yang berjudul pengaruh rasio leverage terhadap profitabilitas (studi pada perusahaan makanan dan minuman yang terdaftar di BEI periode tahun 2009 - 2011, hasil penelitian ini menunjukkan bahwa secara simultan variabel rasio utang atas asset, rasio utang atas ekuitas, rasio utang jangka panjang atas ekuitas dan rasio waktu bunga yang diperoleh berpengaruh signifikan terhadap rasio hasil pengembalian atas ekuitas, sedangkan secara parsial rasio utang atas asset dan rasio utang jangka panjang atas ekuitas berpengaruh negatif dan signifikan terhadap rasio hasil pengembalian atas ekuitas, rasio utang atas ekuitas dan rasio waktu bunga yang diperoleh berpengaruh positif dan signifikan terhadap rasio hasil pengembalian atas ekuitas. Adapun perbedaan penelitian ini dari penelitian sebelumnya terdapat pada objek penelitian dan populasi yang digunakan, objek penelitian ini yaitu pada perusahaan property dan real estate yang terdaftar di Bursa Efek Indonesia pada periode tahun 2015 - 2017, variabel yang digunakan yaitu variabel independen $(\mathrm{X})$, rasio utang atas asset, rasio utang atas ekuitas dan rasio utang jangka panjang atas ekuitas dan variabel dependen $(\mathrm{Y})$ rasio hasil atas pengembalian 


\section{TINJAUAN LITERATUR}

\section{Struktur Modal}

Struktur modal adalah perimbangan jumlah utang jangka pendek yang bersifat permanen, utang jangka panjang, saham preferen dan saham biasa. Sementara itu struktur keuangan adalah perimbangan antara total utang dengan modal sendiri, dengan kata lain struktur modal merupakan bagian dari struktur keuangan (Agus sartono, 2001: 225). Secara umum, perusahaan dapat memilih di antara banyak struktur modal alternatif. Pilihan tersebut dapat dilakukan misalnya dengan cara mengeluarkan sejumlah sekuritas utang atau sebaliknya hanya melihatkan jumlah hutang yang sedikit (Najmudin, 2011: 293). Adapun komponen struktur modal menurut Najmudin (2011: 218 228) sebagai berikut :

\section{Modal Utang}

Utang atau modal asing adalah modal yang berasal dari luar perusahaan yang sifatnya sementara dioperasikan dalam perusahaan. Modal tersebut bagi perusahaan merupakan kewajiban yang pada saatnya harus dibayar kembali, dengan utang ini, perusahaan tidak perlu menyerahkan kepemilikannya. Biaya penggunaan utang seringkali lebih rendah dari pada pembiayaan dari modal sendiri. Pembiayaan modal sendiri berkaitan dengan risiko yang lebih tinggi sehingga para investor meminta perolehan imbalan yang lebih besar dari pada pemberi pinjaman. Mengenai penggolongan utang menurut jangka waktunya, sebagian penulis hanya membaginya menjadi utang jangka pendek (periodenya kurang dari satu tahun) dan utang jangka panjang (lebih dari satu tahun).

\section{Modal sendiri}

Modal sendiri pada dasarnya modal yang berasal dari pemilik perusahaan dan yang tertanam dalam perusahaan. Ditinjau dari sudut likuiditas, modal sendiri merupakan dana jangka panjang yang tidak tertentu waktu - waktunya. Selain dari luar perusahaan (sumber eksternal) yang berupa modal saham dari pemilik perusahaan, modal sendiri dapat juga berasal dari dalam perusahaan sendiri (sumber internal) yang berbentuk laba ditahan.

Pendanaan modal sendiri mencerminkan investasi pribadi dari pemilik, dan kadang - kadang disebut risk capital karena para investor ini mengasumsikan risiko kehilangan dana mereka apabila bisnisnya gagal. Para pemodalnya berhak mendapatkan laba perusahaan dan biasanya memiliki hak suara dalam menentukan masa depan perusahaan. Kerugian utama modal sendiri adalah perusahaan harus memberikan sebagian kepemilikan (kontrol) perusahaan kepada orang luar. Modal sendiri terdiri atas modal saham, cadangan, dan laba ditahan. Berikut ini masing - masing penjelasannya :

a. Modal saham

Saham adalah tanda bukti adanya bagian kepemilikan atau anggota dalam suatu perusahaan. Jenis saham terdiri dari atas saham biasa, saham preferen. Pemegang saham biasa akan mendapatkan dividen jika perusahaan yang bersangkutan memperoleh laba, jika perusahaan tidak memperoleh laba atau mengalami kerugian, maka pemegang saham tidak akan mendapat dividen.

Pemegang saham preferen mempunyai sejumlah preferensi tertentu di atas pemegang saham biasa, terutama dalam dua hal. Pertama adalah pembagian dividen. Dividen untuk pemegang saham preferen diambilkan lebih dahulu dari laba bersih, kemudian sisanya disediakan untuk pemegang saham biasa. Kedua adalah pembagian kekayaan, jika perusahaan di likuidasi, pemegang saham preferen lebih didahulukan dalam pembagian kekayaan dari pada saham biasa. Namun demikian, saham preferen juga mempunyai kelemahan, yaitu pemegang saham preferen tidak mempunyai hak suara dalam rapat umum pemegang saham (RUPS). Adapun persamaanya, baik pemegang saham biasa maupun pemegang saham preferen hanya berhak menerima dividen apabila perusahaan mendapatkan laba. 
b. Cadangan

Cadangkan terbentuk dari laba yang diperoleh selama beberapa waktu yang lalu atau dari tahun yang berjalan. Tidak semua cadangan termasuk dalam pengertian modal sendiri. Cadangan yang termasuk dalam modal sendiri meliputi cadangan ekspansi, cadangan modal kerja, cadangan selisih kurs, dan cadangan untuk menampung hal - hal atau kejadian yang tidak diduga sebelumnya (cadangan umum).

c. Laba Ditahan

Laba yang diperoleh suatu perusahaan sebagian dapat dibayarkan sebagai dividen dan sebagian ditahan oleh perusahaan, jika penahanan laba tersebut sudah mempunyai tujuan tertentu, maka dibentuklah cadangan seperti diuraikan diatas. Sebaliknya, jika perusahaan belum mempunyai tujuan tertentu mengenai penggunaan laba tersebut, maka laba tersebut merupakan laba yang ditahan.

\section{Teori Modigliani dan Miller (MM)}

Menurut Modigliani dan Miller, dalam Najmudin (2011: 297) menyatakan bahwa dalam pasar yang bekerja dengan baik, nilai pasar suatu perusahaan tidak bergantung pada struktur modalnya. Namun demikian, pernyataan MM tersebut didasarkan pada asumsi - asumi yang sangat ketat yang tidak realistis. Asumsi yang dianggap tidak realistis tersebut diantaranya adalah tidak adanya brokerage costs, tidak adanya pajak, tidak adanya biaya kebangkrutan, investor memiliki infromasi yang sama dengan manajemen mengenai peluang investasi, dan tidak terpengaruhnya laba sebelum bunga pajak (EBIT) oleh penggunaan utang, meski asumsi - asumsi yang mendasari teori MM sangat tidak realistis, hasil yang tidak relevan dari teori tersebut sangatlah penting, dengan mengindikasikan kondisi - kondisi yang menunjukkan struktur modal yang tidak relevan MM menyediakan petunjuk tentang kondisi yang memungkinkan struktur modal relevan dan dengan demikian mempengaruhi nilai perusahaan.

\section{Teori Pecking Order}

Menurut Myers (1984), dalam Najmudin (2011: 300) teori ini menunjukkan adanya urutan pemilihan (pecking order) dalam struktur modal. Berdasarkan teori pecking order, di dalamnya terdapat pemikiran sebagai berikut. Pertama, perusahaan memilih sumber pendanaan internal karena dana tersebut diperoleh tanpa mengakibatkan sinyal negatif yang dapat menurunkan harga saham. Kedua, ketika perusahaan membutuhkan sumber pendanaan eksternal, maka tahap pertama adalah menerbitkan utang, sedangkan penerbitan ekuitas dilakukan sebagai langkah terakhir. Hal ini menunjukkan penerbitan utang lebih kecil kemungkinannya dipandang sebagai sinyal buruk oleh para investor.

Teori Trade - off

Teori struktur modal MM mendapatkan kritik yang dikemukakan oleh Stiglitz (1969) dan Rubinstein (1973) dalam bukunya Najmudin (2011: 305) menyatakan bahwa investor tidak mungkin meminjam dan meminjamkan dengan tingkat bunga yang sama, jika perusahaan akan bangkrut, maka akan membayar bunga lebih tinggi dan investor yang menggunakan sekuritas utang yang dikeluarkan perusahaan sebagai jaminan harus membayar bunga lebih tinggi. Artinya, kenaikan utang untuk mencapai struktur modal optimal akan menimbulkan pilihan (trade - off) antara keuntungan pengehemat pajak atas peningkatan utang atau kebangkrutan yang akan terjadi.

\section{Rasio Hasil Pengembalian Atas Ekuitas (ROE)}

Rasio profitabilitas merupakan rasio untuk menilai kemampuan perusahaan dalam mencari keuntungan. Rasio ini juga memberikan ukuran tingkat efektivitas manajemen suatu perusahaan. Hal ini ditunjukkan oleh laba yang dihasilkan dari penjualan dan pendapatan investasi. Indikator dari 
rasio profitabilitas yaitu, margin laba bersih, rasio hasil pengembalian asset, rasio hasil pengembalian ekuitas, pengembalian per saham, rasio hasil pengembalian investasi. Rasio profitabilitas akan diukur menggunakan rasio hasil pengembalian atas ekuitas, rasio hasil pengembalian atas ekuitas (ROE) adalah rasio yang digunakan untuk mengukur kemampuan perusahaan untuk menghasilkan laba dari investasi pemegang saham di perusahaan tersebut, dengan kata lain rasio ini menunjukkan seberapa banyak keuntungan yang dapat dihasilkan oleh perusahaan dari setiap rupiah yang diinvestasikan oleh para pemegang saham, karena rasio ini menunjukkan efisiensi penggunaan modal sendiri makin tinggi rasio ini makin baik, artinya posisi pemilik perusahaan makin kuat, demikan pula sebaliknya (Kasmir, 2010: 115).

\section{Kerangka Teoritik}

Mengetahui pengaruh struktur modal terhadap rasio hasil pengembalian atas ekuitas (ROE) sangat dibutuhkan oleh sebuah perusahaan supaya perusahaan dapat mencapai tujuan jangka panjang perusahaan tersebut, penelitian ini bertujuan untuk mengetahui pengaruh hubungan secara signifikan antara variabel dependen (Y) yaitu rasio hasil atas pengembalian ekuitas (ROE) dengan variabel independen $(\mathrm{X})$ rasio utang atas asset, rasio utang atas ekuitas, rasio utang jangka panjang atas ekutas dan rasio waktu bunga yang diperoleh, maka sebagai dasar untuk merumuskan hipotesis berikut disajikan kerangka teoritik dalam model penelitian pada gambar 1:

\section{Gambar 1}

Kerangka Teoritik



\section{Pengaruh Rasio Utang Atas Asset Terhadap Rasio Hasil Pengembalian Atas Ekuitas (ROE).}

Kasmir (2010: 112) rasio utang atas asset mengukur seberapa besar aktiva perusahaan dibiayai oleh utang. Teori struktur modal model Modigliani dan Miller, dalam Najmudin (2011 297) yang tanpa pajak, menyatakan dimana penggunaan hutang tanpa pajak tidak berpengaruh terhadap nilai perusahaan. Hal ini didukung dengan penelitian Jihan salim (2015) yang berjudul pengaruh leverage (dar, der, dan tier) terhadap roe perusahaan property dan real estate yang terdaftar di bursa efek Indonesia tahun 2010 - 2014 bahwa rasio utang atas asset tidak berpengaruh signifikan terhadap rasio hasil pengembalian atas ekuitas. Penelitian Redy Khoiranto (2010) dengan judul pengaruh struktur modal (dar, der, lder) terhadap roe pada perusahaan manufaktur size besar dan kecil yang listing di bei tahun 2009, hasil penelitian ini menunjukkan bahwa rasio utang atas asset tidak berpengaruh signifikan terhadap rasio hasil pengembalian atas ekuitas. Berdasarkan uraian di atas maka dapat dirumuskan hipotesis sebagai berikut: 
H.1 : Rasio utang atas asset berpengaruh signifikan terhadap rasio hasil pengembalian atas ekuitas (ROE).

\section{Pengaruh Rasio Utang Atas Ekuitas Terhadap Rasio Hasil Pengembalian Atas Ekuitas (ROE).}

Menurut teori Pecking order Myers (1984), dalam Najmudin (2011: 300) perusahaan memilih sumber pendanaan internal karena dana tersebut diperoleh tanpa mengakibatkan sinyal negatif yang dapat menurunkan harga saham, ketika perusahaan membutuhkan sumber pendanaan eksternal, maka tahap pertama adalah menerbitkan hutang, sedangkan penerbitan ekuitas dilakukan sebagai langkah terakhir. Hal ini menunjukkan penerbitan utang lebih kecil kemungkinannya dipandang sebagai sinyal buruk oleh para investor.

Hal ini didukung dengan penelitian Adityo joko (2017) hasil uji antara rasio utang atas ekuitas tidak berpengaruh signifikan terhadap rasio hasil pengembalian atas ekuitas dan penelitian Henny Yulsiati (2016) menunjukkan bahwa rasio utang atas ekuitas tidak berpengaruh signifikan terhadap rasio hasil pengembalian atas ekuitas. Berdasarkan uraian di atas maka dapat dirumuskan hipotesis sebagai berikut:

H.2 : Rasio utang atas ekuitas berpengaruh signifikan terhadap rasio hasil pengembalian atas ekuitas (ROE).

\section{Pengaruh Rasio Utang Jangka Panjang Atas Ekuitas Terhadap Rasio Hasil Pengembalian Atas Ekuitas (ROE).}

Menurut teori Trade - off teori struktur modal MM mendapat kritik yang dikemukakan oleh Stiglitz (1969) dan Rubinstein (1973) dalam bukunya Najmudin (2011: 305) menyatakan bahwa investor tidak mungkin meminjam dan meminjamkan dengan tingkat bunga yang sama, jika perusahaan akan bangkrut maka akan membayar bunga lebih tinggi dan investor yang menggunakan sekuritas utang yang dikeluarkan perusahaan sebagai jaminan harus membayar bunga lebih tinggi. Artinya, kenaikan utang untuk mencapai struktur modal optimal akan menimbulkan pilihan (trade off) antara keuntungan pengehemat pajak atas peningkatan utang atau kebangkrutan yang akan terjadi. Menurut Emma dan Jusmani (2017) hasil uji signifikan antara rasio utang jangka panjang atas ekuitas tidak berpengaruh terhadap rasio hasil pengembalian atas ekuitas, Redy Khoiranto (2010) hasil uji signifikan antara rasio utang jangka panjang atas ekuitas tidak berpengaruh terhadap rasio hasil pengembalian atas ekuitas. Berdasarkan uraian di atas maka dapat dirumuskan hipotesis sebagai berikut:

H.3 : Rasio utang jangka panjang atas ekuitas berpengaruh signifikan terhadap rasio hasil pengembalian atas ekuitas (ROE).

\section{Pengaruh Rasio Waktu Bunga Yang Diperoleh Terhadap Rasio Hasil Pengembalian Atas Ekuitas (ROE).}

Menurut Jihan (2015) hasil penelitian menunjukkan bahwa variabel rasio waktu bunga yang diperoleh berpengaruh positif dan signifikan terhadap rasio hasil pengembalian atas ekuitas, Menurut Kristina dan Leny (2015) menunjukkan bahwa rasio waktu bunga yang diperoleh berpengaruh terhadap rasio hasil pengembalian atas ekuitas. Menurut Dini, dkk (2015) hasil penelitian ini menjelaskan bahwa rasio waktu bunga yang diperoleh signifikan berpengaruh terhadap rasio hasil pengembalian atas ekuitas pada perusahaan industri kimia yang listing di BEI periode 2009- 2013 serta berpengaruh positif dan mempunyai arah yang sama, hal tersebut mengandung arti bahwa semakin tinggi rasio waktu bunga yang diperoleh maka akan semakin tinggi pula rasio hasil 
pengembalian atas ekuitas. Berdasarkan uraian di atas maka dapat dirumuskan hipotesis sebagai berikut:

H.4 : Rasio waktu bunga yang diperoleh berpengaruh signifikan terhadap rasio hasil pengembalian atas ekuitas (ROE).

\section{METODE PENELITIAN}

Penelitian ini dilakukan pada laporan keuangan perusahaan property dan real estate yang terdaftar di Bursa Efek Indonesia melalui website (www.idx.co.id) periode tahun 2015 - 2017. Penelitian ini menggunakan pendekatan asosiatif.

Populasi dalam penelitian ini adalah seluruh perusahaan property dan real estate yang terdaftar di Bursa Efek Indonesia periode tahun 2015 - 2017. Teknik pengambilan sampel pada penelitian ini menggunakan metode purposive sampling yaitu teknik penentuan sampel dengan pertimbangan tertentu (Sugiyono, 2016: 85). Sampel yang digunakan dalam penelitian ini yaitu 41 perusahaan property dan real estate yang terdaftar di bursa efek Indonesia periode tahun 2015 - 2017.

\section{Regresi Linier Berganda}

Analisis regresi linear berganda digunakan oleh peneliti, hanya untuk memberikan penjelasan dan besarnya hubungan (model) antar dua variabel atau lebih, jadi analisis regresi berganda akan dilakukan bila jumlah variabel independennya minimal 2 (Rambat dan Ridho, 2015: 152).

Sumber (Rambat dan Ridho, 2015: 152):

$$
Y=a+b_{1} X_{1}+b_{2} X_{2}+b_{3} X_{3}+\varepsilon
$$

\section{Uji Asumsi Klasik}

\section{A. Uji Normalitas}

Ghozali (2013: 160) uji normalitas bertujuan untuk menguji apakah dalam model regresi, variabel pengganggu atau residual memiliki distribusi normal. Seperti diketahui bahwa uji t dan uji F mengasumsikan bahwa nilai residual mengikuti distribusi normal. Apabila asumsi ini dilanggar maka uji statistik menjadi tidak valid untuk jumlah sampel kecil. (Rambat dan Ridho, 2015: 134) pada uji normalitas data ini menggunakan metode One Sample Kolmogorov-Smirnov Test dengan program SPSS. Penggunaan uji One Sample Kolmogorov-Smirnov Test atau uji K-S termasuk dalam golongan non - parametrik karena peneliti belum mengetahui apakah data yang digunakan termasuk data parametrik atau bukan. Pada uji K-S, data dikatakan normal apabila nilai Sign > 0,05. Tujuan pengujian ini adalah untuk mengetahui apakah sampel yang digunakan dalam penelitian ini berdistribusi normal atau tidak.

\section{B. Uji Multikolinieritas}

Ghozali (2013:105) uji multikolinieritas dilakukan untuk menguji apakah model regresi ditemukan adanya korelasi antar variabel bebas (independen). Model regresi yang baik seharusnya tidak terjadi korelasi di antara variabel independen, jika variabel independen saling berkorelasi, maka variabel - variabel ini tidak orthogonal. Variabel orthogonal adalah variabel independen yang nilai korelasi antar sesama variabel independen sama dengan nol. Salah satu metode untuk menguji ada tidaknya multikolinieritas pada penelitian ini menggunakan pengujian Variance Inflation Factor (VIF) menggunakan program SPSS. Besaran VIF (Variance Inflation Factor) dan Tolerance. Model regresi yang bebas multikolinieritas yaitu mempunyai nilai VIF $<10$ dan mempunyai angka tolerance mendekati 1. 


\section{Uji Heteroskedastisitas}

Salah satu untuk menguji ada tidaknya heteroskedastisitas pada penelitian ini adalah dengan menggunakan Uji Glejser pada program SPSS. Dasar pengambilan keputusan yaitu secara statistik variabel independen dikatakan tidak signifikan karena > 0,05 (5\%), sehingga semakin tidak signifikan variabel penjelas mengindikasikan bahwa model sudah terbebas dari gejala heteroskedastisitas.

\section{Uji Autokorelasi}

Ghozali (2013: 110) uji autokorelasi bertujuan menguji apakah dalam model regresi linier ada korelasi antara kesalahan pengganggu pada periode $t$ dengan kesalahan pengganggu pada periode $t-1$ (sebelumnya), jika terjadi korelasi maka dinamakan ada problem autokorelasi. Autokorelasi muncul karena observasi yang berurutan sepanjang waktu berkaitan satu sama lainnya. Hal ini sering ditemukan pada data runtut waktu (time series). Selanjutnya untuk mendeteksi adanya autokorelasi dalam analisis regresi linier berganda dapat digunkanan metode Durbin - Watson (DW test).

Pengambilan keputusan ada tidaknya autokorelasi ditentukan berdasarkan kriteria berikut:

1. Jika $\mathrm{d}<\mathrm{dl}$, berarti terdapat autokorelasi positif.

2. Jika $\mathrm{d}>(4-\mathrm{dl})$, berarti terdapat autokorelasi negatif.

3. Jika du $<\mathrm{d}<(4-\mathrm{dl})$, berarti tidak terdapat autokorelasi.

4. Jika $\mathrm{dl}<\mathrm{d}<\mathrm{du}$ atau $(4-\mathrm{du})$, berarti tidak dapat disimpulkan.

\section{E. Uji Hipotesis}

Uji ini digunakan untuk menjelaskan kekuatan dan arah pengaruh variabel independen rasio utang atas asset (X1), rasio utang atas ekuitas (X2), rasio utang jangka panjang atas ekuitas (X3), dan rasio waktu bunga yang diperoleh (X4) terhadap satu variabel dependen (Y) yaitu rasio hasil pengembalian atas ekuitas (ROE). Uji hipotesis dilakukan sebagai berikut: uji signifikansi (pengaruh nyata) variabel independen (X) terhadap variabel dependen (Y) baik secara parsial maupun secara simultan, dilakukan uji statistik $\mathrm{t}(\mathrm{t}$ - test) dan uji $\mathrm{F}$ dengan menggunakan program SPSS.

\section{HASIL DAN PEMBAHASAN \\ Regresi Linier Berganda}

Persamaan regresi dapat dilihat dari tabel hasil uji coefficients hasil output SPSS versi 20 terhadap keempat variabel independen yaitu ditunjukkan pada tabel 7 berikut :

\section{Tabel 7}

Hasil Regresi Linier Berganda

\section{Coefficients $^{a}$}

\begin{tabular}{|c|c|c|c|c|c|c|c|}
\hline \multirow[t]{2}{*}{ Model } & \multicolumn{2}{|c|}{$\begin{array}{l}\text { Unstandardized } \\
\text { Coefficients }\end{array}$} & \multirow{2}{*}{$\begin{array}{c}\text { Standardized } \\
\text { Coefficients }\end{array}$} & \multirow[t]{2}{*}{$\mathrm{T}$} & \multirow[t]{2}{*}{ Sig. } & \multicolumn{2}{|c|}{ Collinearity Statistics } \\
\hline & $B$ & $\begin{array}{l}\text { Std. } \\
\text { Error }\end{array}$ & & & & Tolerance & VIF \\
\hline (Constant) & .018 & .025 & & .714 & .477 & & \\
\hline DR & .097 & .123 & .191 & .788 & .433 & .108 & 9.295 \\
\hline 1 DER & .015 & .032 & .103 & .468 & .641 & .131 & 7.643 \\
\hline LDER & -.040 & .030 & -.158 & -1.340 & .183 & .456 & 2.192 \\
\hline TIER & .003 & .000 & .496 & 6.062 & .000 & .942 & 1.062 \\
\hline
\end{tabular}

a. Dependent Variable: $\mathrm{ROE}$

Sumber : Data diolah, 2019 
Tabel diatas didapat persamaan model regresi yang digunakan adalah sebagai berikut.

$$
\mathrm{Y}=0.018+0.097\left(\mathrm{X}_{1}\right)+0.015\left(\mathrm{X}_{2}\right)-0.040\left(\mathrm{X}_{3}\right)+0.003\left(\mathrm{X}_{4}\right)+\varepsilon
$$

a. Konstanta variabel (Y) rasio hasil pengembalian atas ekuitas (ROE) sebesar 0.018 menunjukkan bahwa jika variabel - variabel independen diasumsikan tidak mengalami perubahan (konstan), yang artinya ketika variabel $(\mathrm{X})$ bernilai nol maka pertumbuhan rasio hasil pengembalian atas ekuitas (ROE) akan meningkat sebesar 0.018 .

b. Koefisien variabel DR (rasio utang atas asset) sebesar 0.097 berarti setiap kenaikan DR (rasio utang atas asset) sebesar satu satuan rasio hasil pengembalian atas ekuitas (ROE) akan naik sebesar 0.097.

c. Koefisien variabel DER (rasio utang atas ekuitas) sebesar 0.015 menunjukkan bahwa setiap terjadi kenaikan DER (rasio utang atas ekuitas) sebesar satu satuan maka rasio hasil pengembalian atas ekuitas (ROE) akan naik sebesar 0.015 .

d. Koefisien variabel LDER (rasio utang jangka panjang atas ekuitas) sebesar -0.040 artinya jika variabel LDER (rasio utang jangka panjang atas ekuitas) mengalami kenaikan sebesar satu satuan, maka rasio hasil pengembalian atas ekuitas (ROE) akan turun sebesar -0.040.

e. Koefisien variabel TIER (rasio waktu bunga yang diperoleh) sebesar 0.003 menunjukkan bahwa setiap terjadi kenaikan variabel TIER (rasio waktu bunga yang diperoleh) sebesar satu satuan maka rasio hasil pengembalian atas ekuitas (ROE) akan naik sebesar 0.003.

\section{Uji Asumsi Klasik}

\section{Uji Normalitas}

Uji One Sample Kolmogorov - Smirnov Test atau K - S, data dikatakan berdistribusi normal apabila nilai sign >0,05. Hasil uji normalitas menggunakan One Sample Kolmogorov Smirnov Test dapat dilihat pada tabel 8 berikut :

\section{Tabel 8}

Hasil Uji Normalitas

\begin{tabular}{|ll|r|}
\hline \multicolumn{2}{|c|}{ One-Sample Kolmogorov-Smirnov Test } \\
\hline $\mathrm{N}$ & & Unstandardized Residual \\
Normal Parameters ${ }^{\mathrm{a}, \mathrm{b}}$ & Mean & 123 \\
& Std. Deviation & $0 \mathrm{E}-7$ \\
& Absolute & .07817112 \\
Most Extreme Differences & Positive & .096 \\
& Negative & .096 \\
Kolmogorov-Smirnov Z & & -.096 \\
Asymp. Sig. (2-tailed) & & 1.069 \\
\hline
\end{tabular}

a. Test distribution is Normal.

b. Calculated from data.

Sumber : Data diolah, 2019

Nilai signifikansi sebesar 0.204 menunjukkan bahwa signifikansinya jauh lebih besar dari 0.05 atau 5\%, maka dapat disimpulkan bahwa variabel - variabel tersebut berdistribusi normal.

\section{Uji Multikolinieritas}

Model regresi yang baik seharusnya tidak terjadi korelasi di antara variabel independen. Hasil uji multikolinieritas menggunakan Variance Inflation Factor (VIF) pada tabel 9 berikut : 
Tabel 9

Hasil uji Multikolinieritas

Coefficients $^{a}$

\begin{tabular}{|c|c|c|c|c|c|c|c|}
\hline \multirow[t]{2}{*}{ Model } & \multicolumn{2}{|c|}{$\begin{array}{c}\text { Unstandardized } \\
\text { Coefficients }\end{array}$} & \multirow{2}{*}{$\begin{array}{c}\begin{array}{c}\text { Standardized } \\
\text { Coefficients }\end{array} \\
\text { Beta }\end{array}$} & \multirow[t]{2}{*}{$\mathrm{t}$} & \multirow[t]{2}{*}{ Sig. } & \multicolumn{2}{|c|}{ Collinearity Statistics } \\
\hline & B & $\begin{array}{l}\text { Std. } \\
\text { Error }\end{array}$ & & & & Tolerance & VIF \\
\hline (Constant) & .018 & .025 & & .714 & .477 & & \\
\hline $\mathrm{DR}$ & .097 & .123 & .191 & .788 & .433 & .108 & 9.295 \\
\hline 1 DER & .015 & .032 & .103 & .468 & .641 & .131 & 7.643 \\
\hline LDER & -.040 & .030 & -.158 & -1.340 & .183 & .456 & 2.192 \\
\hline TIER & .003 & .000 & .496 & 6.062 & .000 & .942 & 1.062 \\
\hline
\end{tabular}

a. Dependent Variable: ROE

Sumber : Data diolah, 2019

Uji multikolinieritas apabila nilai tolerance $>0,1(10 \%)$ dan VIF $<10$ berarti data bebas dari multikolinieritas. Hasil pengujian menunjukkan bahwa seluruh data perusahaan mempunyai nilai tolerance $>0,1(10 \%)$ dan VIF $<10$, jadi dapat disimpulkan bahwa tidak terjadi multikolinieritas antara variabel independen dan model regresi.

\section{Uji Heteroskedastisitas}

Hasil uji heteroskedastisitas menggunakan uji Glejser dapat dilihat pada tabel 10 berikut :

\section{Tabel 10}

Hasil Uji Glejser

Coefficients $^{\mathrm{a}}$

\begin{tabular}{|c|c|c|c|c|c|c|c|}
\hline \multirow[t]{2}{*}{ Model } & \multicolumn{2}{|c|}{$\begin{array}{l}\text { Unstandardized } \\
\text { Coefficients }\end{array}$} & $\begin{array}{c}\text { Standardized } \\
\text { Coefficients }\end{array}$ & \multirow[t]{2}{*}{$\mathrm{T}$} & \multirow[t]{2}{*}{ Sig. } & \multicolumn{2}{|c|}{ Collinearity Statistics } \\
\hline & $B$ & Std. Error & Beta & & & Tolerance & VIF \\
\hline (Constant) & .043 & .017 & & 2.548 & .012 & & \\
\hline DR & -.039 & .084 & -.124 & -.460 & .646 & .108 & 9.295 \\
\hline 1 DER & .037 & .022 & .417 & 1.708 & .090 & .131 & 7.643 \\
\hline LDER & -.025 & .020 & -.162 & -1.238 & .218 & .456 & 2.192 \\
\hline TIER & .001 & .000 & .178 & 1.952 & .053 & .942 & 1.062 \\
\hline
\end{tabular}

a. Dependent Variable: abresid

Sumber : Data diolah, 2019

Hasil uji Glejser menunjukkan bahwa pada berbagai tahap siklus perusahaan, tidak ada variabel yang menunjukkan signifikansi dibawah $0.05(5 \%)$, maka dapat disimpulkan bahwa tidak terjadi heteroskedastisitas pada setiap variabel.

\section{Uji Autokorelasi}

Hasil uji autokorelasi menggunakan metode Durbin - Watson (DW test) dapat dlihat pada tabel 11 berikut :

\section{Tabel 11}

Hasil Uji Durbin - Watson (Dw Test)

Model Summaryb

\begin{tabular}{l|c|r|r|r|r|}
\hline Model & $\mathrm{R}$ & $\mathrm{R}$ Square & Adjusted R Square & Std. Error of the Estimate & Durbin-Watson \\
\hline 1 & $.505^{\mathrm{a}}$ & .255 & .230 & .07948501 & 1.872 \\
\hline
\end{tabular}

Sumber : Data diolah, 2019 
Dari output diatas nilai dw bernilai 1.872 sedangkan nilai dw tabel dengan jumlah variabel 4 , intercept 1 dan jumlah sampel 123, nilai dl yaitu 1.639 dan nilai du yaitu 1.773. Sehingga dapat disimpulkan nilai dw output berada diantara $\mathrm{du}<\mathrm{d}<(4-\mathrm{dl})$ yaitu $1.773<1.872<2.361$ yang berarti tidak terdapat autokorelasi.

\section{Hasil Uji Hipotesis \\ Uji t-statistik}

Pengaruh rasio utang atas asset, rasio utang atas ekuitas, rasio utang jangka panjang atas ekuitas, rasio waktu bunga yang diperoleh secara parsial terhadap rasio hasil pengembalian atas ekuitas (ROE) dapat diketahui dari hasil uji t yang terdapat pada tabel 10 berikut :

Tabel 10

Uji t-statistik (Uji Parsial)

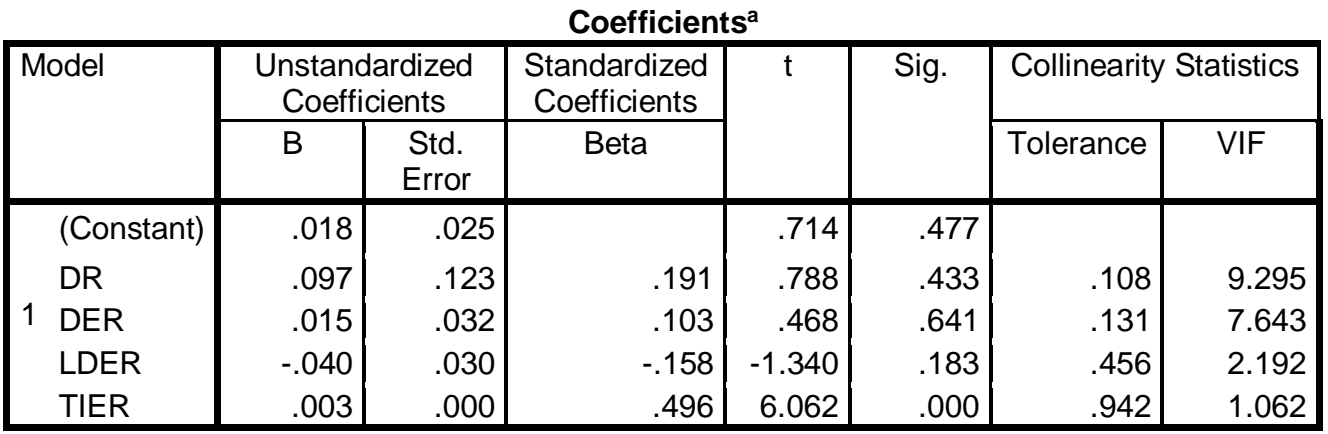

a. Dependent Variable: ROE

Sumber : Data diolah, 2019 sebagai berikut:

Berdasarkan Uji t- statistik di atas, pengujian hipotesis dalam penelitian ini dijelaskan

1. Hipotesis 1

Berdasarkan tabel hasil uji t menunjukkan bahwa nilai signifikansi dari variabel DR (rasio utang atas asset) yaitu sebesar 0.433 dan nilai koefisien regresi (B) sebesar 0.097. Hasil signifikansi tersebut lebih besar dari $\alpha(0.05)$, maka $H_{0}$ diterima dan $H_{1}$ ditolak yang berarti bahwa variabel DR (rasio utang atas asset) tidak berpengaruh signifikan terhadap variabel rasio hasil pengembalian atas ekuitas (ROE). Sehingga dapat disimpulkan hipotesis pertama (H1) ditolak.

2. Hipotesis 2

Berdasarkan tabel hasil uji t menunjukkan bahwa nilai signifikansi dari variabel DER (rasio utang atas ekuitas) yaitu sebesar 0.641 dan nilai koefisien regresi (B) sebesar 0.015. Hasil signifikansi tersebut lebih besar dari $\alpha(0.05)$, maka $H_{0}$ diterima dan $H_{2}$ ditolak yang artinya variabel DER (rasio utang atas ekuitas) tidak berpengaruh signifikan terhadap variabel rasio hasil pengembalian atas ekuitas (ROE). Sehingga dapat disimpulkan hipotesis kedua (H2) ditolak.

3. Hipotesis 3

Berdasarkan tabel hasil uji t menunjukkan bahwa nilai signifikansi dari variabel LDER (rasio utang jangka panjang atas ekuitas) yaitu sebesar 0.183 dan nilai koefisien regresi (B) sebesar 0.040 . Hasil signifikansi tersebut lebih besar dari $\alpha(0.05)$, maka $H_{0}$ diterima dan $H_{3}$ ditolak yang berarti bahwa variabel LDER (rasio utang jangka panjang atas ekuitas) tidak berpengaruh terhadap variabel rasio hasil pengembalian atas ekuitas (ROE). Sehingga dapat disimpulkan hipotesis ketiga $(\mathrm{H} 3)$ ditolak. 


\section{Hipotesis 4}

Berdasarkan tabel hasil uji t menunjukkan bahwa nilai signifikansi dari variabel TIER (rasio waktu bunga yang diperoleh) yaitu sebesar 0.000 dan nilai koefisien regresi (B) sebesar 0.003 . Hasil signifikansi tersebut lebih kecil dari $\alpha$ (0.05) dan nilai koefisien regresi (B) positif bernilai 0.003 artinya untuk setiap peningkatan variabel TIER (rasio waktu bunga yang diperoleh) sebesar satu satuan maka rasio hasil pengembalian atas ekuitas (ROE) akan meningkat sebesar 0.003, maka $H_{0}$ ditolak dan $H_{4}$ diterima yang berarti bahwa variabel TIER (rasio waktu bunga yang diperoleh) berpengaruh signifikan terhadap variabel rasio hasil pengembalian atas ekuitas (ROE). Sehingga dapat disimpulkan hipotesis keempat $(\mathrm{H} 4)$ diterima.

\section{Uji F- statistik}

Hasil uji F (Simultan) dapat dilihat pada tabel 11 berikut:

\section{Tabel 11}

Uji F - statistik

\begin{tabular}{|l|r|r|r|c|c|}
\hline \multicolumn{7}{|c|}{ ANOVA $^{\mathrm{a}}$} \\
\hline Model & Sum of Squares & \multicolumn{1}{c|}{$\mathrm{df}$} & Mean Square & $\mathrm{F}$ & Sig. \\
\hline Regression & .255 & 4 & .064 & 10.102 & $.000^{\mathrm{b}}$ \\
1 Residual & .746 & 118 & .006 & & \\
Total & 1.001 & 122 & & & \\
\hline
\end{tabular}

a. Dependent Variable: ROE

b. Predictors: (Constant), TIER, LDER, DER, DR

\section{Sumber : Data diolah, 2019}

Berdasarakan hasil dari uji statistik $\mathrm{F}$ pada tabel diatas, menunjukkan bahwa nilai signifikan yaitu sebesar 0.000 lebih kecil dari nilai signifikan $\alpha=0,05$ yang memiliki arti bahwa $H_{0}$ ditolak dan $H_{5}$ diterima, yang artinya rasio utang atas asset, rasio utang atas ekuitas dan rasio utang jangka panjang atas ekuitas, dan rasio waktu bunga yang diperoleh secara simultan berpengaruh signifikan terhadap rasio hasil pengembalian atas ekuitas (ROE).

\section{Hasil Uji Koefisien Determinasi $\left(R^{2}\right)$}

Kekuatan pengaruh variabel independen terhadap variasi variabel dependen dapat diketahui dari besarnya nilai koefisien determinan $\left(R^{2}\right)$ yang berada antara nol dan satu, nilai $\left(\mathrm{R}^{2}\right)$ yang kecil berarti kemampuan variabel - variabel independen dalam menjelaskan variasi variabel dependen sangat terbatas. Nilai yang mendekati satu berarti variabel independen memberikan hampir semua informasi yang dibutuhkan untuk memprediksi variasi variabel dependen. Hasil uji $\left(R^{2}\right)$ dapat dilihat pada tabel 12 berikut :

Tabel 12

Uji Koefisien Determinasi $\left(R^{2}\right)$

\begin{tabular}{|l|r|r|c|c|r|}
\hline Model & $\mathrm{R}$ & R Square & $\begin{array}{c}\text { Adjusted R } \\
\text { Square }\end{array}$ & $\begin{array}{c}\text { Std. Error of the } \\
\text { Estimate }\end{array}$ & Durbin-Watson \\
\hline 1 & $.505^{\mathrm{a}}$ & .255 & .230 & .07948501 & 1.872 \\
\hline
\end{tabular}
a. Predictors: (Constant), TIER, LDER, DER, DR
b. Dependent Variable: ROE

\section{Sumber : Data diolah, 2019}

Pada tabel 12 bahwa koefisien korelasi (R) yang terjadi antara rasio utang atas asset, rasio utang atas ekuitas, rasio utang jangka panjang atas ekuitas dan rasio waktu bunga yang diperoleh 
sebagai variabel independen dengan rasio hasil pengembalian atas ekuitas (ROE) bernilai 0.230 yang artinya kemampuan variabel independen dalam menjelaskan variasi variabel dependen sebesar 0.230, sedangkan sisanya dijelaskan oleh variabel lainnya diluar variabel independen yang tidak dimasukkan dalam model regresi pada penelitian ini.

\section{Pembahasan}

\section{Pengaruh Rasio Utang Atas Asset Terhadap Rasio Hasil Pengembalian Atas Ekuitas (ROE).}

Hasil penelitian menunjukkan bahwa rasio utang atas asset (DR) tidak berpengaruh signifikan terhadap rasio hasil pengembalian atas ekuitas (ROE), dengan tingkat signifikansi $0.433>$ $\alpha$ (0.05). Berdasarkan analisis regresi linier berganda, hasil menunjukkan koefisien sebesar 0.097 menyatakan bahwa setiap peningkatan rasio utang atas asset (DR) sebesar satu satuan maka akan menyebabkan peningkatan rasio hasil pengembalian atas ekuitas (ROE) sebesar 0.097 satuan, dengan asumsi variabel yang lainnya konstan. Sedangkan hasil uji hipotesis menunjukkan bahwa H1 ditolak, yaitu rasio utang atas asset (DR) tidak berpengaruh signifikan terhadap rasio hasil pengembalian atas ekuitas (ROE).

Fokus investor tidak pada nilai rasio utang atas asset (DR) perusahaan yang berarti bahwa nilai rasio utang atas asset (DR) tidak mempengaruhi minat investor dalam mempertimbangkan keputusan pembelian saham. Investor lebih memilih memperhatikan prospek perusahaan dibandingkan dengan tingkat rasio utang atas asset (DR), sehingga naik maupun turunnya nilai rasio utang atas asset (DR) tidak diikuti oleh naik turunnya nilai rasio hasil pengembalian atas ekuitas (ROE), hal ini disebabkan oleh data rasio utang atas asset (DR) pada penelitian ini memiliki rata-rata yang cukup rendah, yaitu hanya setengah dari rata-rata rasio utang atas ekuitas (DER). Rata-rata rasio utang atas asset (DR) dari tahun 2015 - 2017 yaitu sebesar 0.39, sedangkan rata-rata rasio utang atas ekuitas (DER) dari tahun 2015 - 2017 yaitu 0.80 sampai 0.83 atau kemungkinan lainnya yaitu perusahaan tidak terlalu berfokus pada pengalokasian utang dalam pembiayaan aktiva, melainkan bagaimana beban yang timbul atas utang tersebut dapat ditutup dengan tetap menerima bagian keuntungan yang besar. Hasil penelitian ini sama dengan penelitian sebelumnya yang dilakukan Jihan salim (2015) dan Redy Khoiranto (2010) menunjukkan bahwa rasio utang atas asset tidak berpengaruh signifikan terhadap rasio hasil pengembalian atas ekuitas.

\section{Pengaruh Rasio Utang Atas Ekuitas Terhadap Rasio Hasil Pengembalian Atas Ekuitas (ROE).}

Hasil penelitian menunjukkan bahwa rasio utang atas ekuitas (DER) tidak berpengaruh signifikan terhadap rasio hasil pengembalian atas ekuitas (ROE), dengan tingkat signifikansi $0.641>$ $\alpha(0.05)$. Berdasarkan analisis regresi linier berganda, hasil menunjukkan koefisien sebesar 0.015 menyatakan bahwa setiap peningkatan rasio utang atas ekuitas (DER) sebesar satu satuan maka akan menyebabkan peningkatan rasio hasil pengembalian atas ekuitas (ROE) sebesar 0.015 satuan, dengan asumsi variabel yang lainnya konstan. Sedangkan hasil uji hipotesis menunjukkan bahwa $\mathrm{H} 2$ ditolak, yaitu rasio utang atas ekuitas tidak berpengaruh signifikan terhadap rasio hasil pengembalian atas ekuitas (ROE).

Tidak berpengaruhnya rasio utang atas ekuitas (DER) terhadap rasio hasil pengembalian atas ekuitas (ROE) mengindikasikan bahwa sebagian besar peminjam (kreditur) menginginkan laba jangka pendek berupa capital gain, hal ini mungkin terjadi karena peminjam (kreditur) dalam melakukan investasi tidak memandang penting penggunaan utang maupun pengembalian bunga yang pada akhirnya tidak mempengaruhi persepsi peminjam (kreditur) terhadap keuntungan di masa 
yang akan datang, hal tersebut dapat dijelaskan apabila nilai rasio utang atas ekuitas (DER) rendah menandakan struktur permodalan usaha tidak terlalu memanfaatkan utang terhadap ekuitas, dan bisa dipahami jika biaya yang dipinjam lebih kecil ini biaya modal sendiri maka sumber dana dari perusahaan akan efektif dalam menghasilkan laba, Semakin rendah rasio utang atas ekuitas (DER) menunjukkan semakin kecil beban perusahaan terhadap pihak luar (kreditur). Hasil penelitian ini sama dengan penelitian sebelumnya yang dilakukan Adityo joko (2017) dan Henny Yulsiati (2016) menunjukkan bahwa rasio utang atas ekuitas tidak berpengaruh signifikan terhadap rasio hasil pengembalian atas ekuitas.

\section{Pengaruh Rasio Utang Jangka Panjang Atas Ekuitas Terhadap Rasio Hasil Pengembalian Atas Ekuitas (ROE).}

Hasil penelitian menunjukkan bahwa rasio utang jangka panjang atas ekuitas (LDER) tidak berpengaruh signifikan terhadap rasio hasil pengembalian atas ekuitas (ROE), dengan tingkat signifikansi $0.183>\alpha(0.05)$. Berdasarkan analisis regresi linier berganda, hasil menunjukkan koefisien sebesar -0.040 menyatakan bahwa setiap peningkatan rasio utang jangka panjang atas ekuitas (LDER) sebesar satu satuan maka akan menyebabkan penurunan rasio hasil pengembalian atas ekuitas (ROE) sebesar -0.040 satuan. Sedangkan hasil uji hipotesis menunjukkan bahwa $\mathrm{H} 3$ ditolak, yaitu rasio utang jangka panjang atas ekuitas (LDER) tidak berpengaruh signifikan terhadap rasio hasil pengembalian atas ekuitas (ROE).

Rasio utang jangka panjang atas ekuitas (LDER) tidak berpengaruh signifikan terhadap rasio hasil pengembalian atas ekuitas (ROE), disebabkan karena sebagian besar perusahaan property dan real estate ini memiliki utang jangka pendek yang lebih besar daripada utang jangka panjangnya, dilihat dari sampel sebanyak 41 perusahaan pada tahun 2015 rata - rata utang jangka panjang sebesar 2.66 sedangkan rata - rata utang jangka pendek sebesar 7.03, tahun 2016 rata - rata utang jangka panjang sebesar 3.19 sedangkan rata - rata utang jangka pendek sebesar 49.12 dan tahun 2017 rata - rata utang jangka panjang sebesar 2.41 sedangkan rata - rata utang jangka pendek sebesar 43.06. Perbandingan utang jangka panjang yang lebih rendah daripada utang jangka pendek mengindikasikan bahwa perusahaan property dan real estate periode tahun 2015 - 2017 tidak menggunakan banyak hutang jangka panjang untuk investasi yang dapat meningkatkan keuntungan sehingga hal ini menyebabkan hasil penelitian menunjukkan rasio utang jangka panjang atas ekuitas (LDER) tidak berpengaruh signifikan terhadap rasio hasil pengembalian atas ekuitas (ROE), yang artinya bahwa tinggi rendahnya utang jangka panjang pada perusahaan tidak akan mempengaruhi tinggi rendahnya rasio hasil pengembalian atas ekuitas (ROE) perusahaan karena utang jangka panjang mempunyai jatuh tempo dan biaya yang pasti, perusahaan dapat menggunakan hal tersebut sebagai bahan pertimbangan dalam mengambil keputusan. Penelitian ini sama dengan penelitian sebelumnya yang dilakukan Emma, Jusmani (2017) dan Redy Khoiranto (2010) menunjukkan bahwa rasio utang jangka panjang atas ekuitas tidak berpengaruh terhadap rasio hasil pengembalian atas ekuitas.

\section{Pengaruh Rasio Waktu Bunga Yang Diperoleh Terhadap Rasio Hasil Pengembalian Atas Ekuitas (ROE)}

Hasil penelitian menunjukkan bahwa rasio waktu bunga yang diperoleh (TIER) berpengaruh signifikan terhadap rasio hasil pengembalian atas ekuitas (ROE), dengan tingkat signifikansi $0.000<\alpha(0.05)$. Berdasarkan analisis regresi linier berganda, hasil menunjukkan koefisien sebesar 0.003 menyatakan bahwa setiap peningkatan rasio waktu bunga yang diperoleh 
(TIER) sebesar satu satuan maka akan menyebabkan peningkatan rasio hasil pengembalian atas ekuitas (ROE) sebesar 0.003 satuan. Sedangkan hasil uji hipotesis menunjukkan bahwa H4 diterima, yaitu rasio waktu bunga yang diperoleh (TIER) berpengaruh signifikan terhadap rasio hasil pengembalian atas ekuitas (ROE). Penelitian ini sama dengan penelitian Jihan (2015), Kristina dan Leny (2015) dan Dini, dkk (2015) yang menunjukkan bahwa rasio waktu bunga yang diperoleh berpengaruh positif dan signifikan terhadap rasio hasil pengembalian atas ekuitas. Tingginya nilai rasio waktu bunga yang diperoleh (TIER) menandakan bahwa keuntungan yang dihasilkan perusahaan jauh lebih besar dari pada beban bunganya. Apabila perusahaan mampu menyelesaikan beban bunganya dengan baik, maka bagian laba yang tersedia untuk pemegang saham rasio hasil pengembalian atas ekuitas juga akan besar. Semakin tinggi rasio ini maka semakin baik rasio hasil pengembalian atas ekuitas (ROE) yang ditunjukkan oleh perusahaan.

Pengaruh Rasio Utang Atas Asset, Rasio Utang Atas Ekuitas, Rasio Utang Jangka Panjang Atas Ekuitas, Rasio Waktu Bunga Yang Diperoleh Secara Simultan Terhadap Rasio Hasil Pengembalian Atas Ekuitas (ROE).

Nilai variabel independen rasio utang atas asset (X1), rasio utang atas ekuitas (X2), rasio utang jangka panjang atas ekuitas (X3), rasio waktu bunga yang diperoleh (X4) dilihat dari nilai signifikansi $0.000<\alpha(0.05), H_{0}$ ditolak dan $H_{5}$ diterima yang berarti rasio utang atas asset, rasio utang atas ekuitas dan rasio utang jangka panjang atas ekuitas, dan rasio waktu bunga yang diperoleh secara simultan berpengaruh signifikan terhadap rasio hasil pengembalian atas ekuitas (ROE). Hal ini sejalan dengan penelitian sebelumnya yang dilakukan oleh Kristina, Leny dan Irmadelia, dkk yang menunjukkan bahwa rasio utang atas asset, rasio utang atas ekuitas, rasio utang jangka panjang atas ekuitas, rasio waktu bunga yang diperoleh mempunyai pengaruh yang signifikan terhadap rasio hasil pengembalian atas ekuitas.

\section{PENUTUP}

1. Pengaruh secara parsial masing - masing variabel independen terhadap variabel dependen yaitu rasio hasil pengembalian atas ekuitas (ROE) sebagai berikut :

a. Rasio utang atas asset tidak berpengaruh signifikan terhadap rasio hasil pengembalian atas ekuitas (ROE).

b. Rasio utang atas ekuitas tidak berpengaruh signifikan terhadap rasio hasil pengembalian atas ekuitas (ROE).

c. Rasio utang jangka panjang atas ekuitas tidak berpengaruh signifikan terhadap rasio hasil pengembalian atas ekuitas (ROE).

d. Rasio waktu bunga yang diperoleh berpengaruh signifikan terhadap rasio hasil pengembalian atas ekuitas (ROE).

2. Secara simultan struktur modal yang diwakili rasio utang atas asset, rasio utang atas ekuitas, rasio utang jangka panjang atas ekuitas, dan rasio waktu bunga yang diperoleh berpengaruh signifikan terhadap rasio hasil pengembalian atas ekuitas (ROE) pada perusahaan property dan real estate periode tahun 2015 - 2017. 


\section{Saran}

Saran untuk perusahaan, agar memperhatikan struktur modal yaitu rasio utang atas asset, rasio utang atas ekuitas, dan rasio waktu yang diperoleh, namun lebih memfokuskan pada struktur modal (rasio waktu bunga yang diperoleh) karena dalam penelitian pada perusahaan property dan real estate yang terdaftar dibursa efek Indonesia periode 2015 - 2017 berpengaruh signifikan terhadap rasio hasil pengembalian atas ekuitas (ROE). Saran untuk penelitian selanjutnya sebaiknya meningkatkan atau menambah jumlah sampel perusahaan, menambah periode penelitian, dan menambah variabel penelitian independen dan dependen lain diluar variabel yang telah diteliti sehingga diperoleh hasil penelitian yang lebih baik.

\section{DAFTAR PUSTAKA}

Adityo Joko, (2017). “ Pengaruh Debt Ro Equity Ratio (DER) Dan Current Ratio (CR) Terhadap Retrun On Equity (ROE), Studi Empiris Pada Perusahaan Sub Sektor Kabel Yang Terdaftar Di Bursa Efek Indonesia Pada Tahun 2013 - 2016”. Ejournal Administrasi Bisnis, Vol 5 No 04 Tahun 2017.

Ansoriyah Fadhilah, (2012). "Pengaruh Struktur Modal Terhadap Kinerja Keuangan Perusahaan : Studi Kasus Pada Perusahaan Sektor Pertambangan Yang Tercatat Di Bursa Efek Indonesia, 2005-2011”. Kajian Ekonomi dan Keuangan, Vol 16 No 1 tahun 2012.

Dini, dkk (2015). "Pengaruh Financial Leverage Terhadap Profitabilitas : Studi Pada Perusahaan Industri Kimia Yang Listing Di BEI Periode 2009 - 2013”. Administrasibisnis.studentjournal, Vol 1 No 1 Januari 2015, Universitas Brawijaya Malang.

Edi Riadi, (2016). Statistika Penelitian : Analisis Manual dan IBM SPSS, Yogyakarta.

Elisa dan Aditya, (2013). “Analisis Pengaruh Struktur Modal Terhadap Profitabilitas”. Diponogoro Journal Of Accounting, Vol 2 No 3 tahun 2013, Universitas Diponogoro.

Emma dan Jusmani, (2017). "Pengaruh Financial Leverage Terhadap Profitabilitas Perusahaan Subsektor Otomotif Dan Komponen Di Bursa Efek Indonesia". JEMBATAN (Jurnal Ekonomi, Manajemen, Bisnis, Auditing, Dan Akuntansi), Vol.2, No.1, Juni 2017. Universitas PGRI Palembang.

Harmono, (2011). Manajemen Keuangan: Berbasis Balanced Scorecard, Jakarta.

Henny Yulsiati, (2016). "Pengaruh Debt To Assets Ratio, Debt To Equity Ratio Dan Net Profit Margin Terhadap Return On Equity Pada Perusahaan Property Dan Real Estate Yang Terdaftar Di Bursa Efek Indonesia”. Jurnal Akuntanika, Vol 1 No 2 Tahun 2016, Universitas Negeri Sriwijaya.

Imam Ghozali. (2013). Aplikasi Analisi Multivariate Dengan Program IBM SPSS 21, Semarang. Irmadelia, dkk (2014). "Pengaruh Rasio Leverage Terhadap Profitabilitas (Studi Pada Perusahaan Makanan Dan Minuman Yang Terdaftar Di Bei Periode Tahun 2009 - 2011)". Jurnal Administrasi Bisnis, Vol. 8 No. 2 Maret 2014|, Malang : Universitas Brawijaya

Jihan Salim (2015), "Pengaruh Leverage (Dar, Der Dan Tier) Terhadap Roe Perusahaan Property Dan Real Estate Yang Terdaftar Di Bursa Efek Indonesia Tahun 2010 - 2014). Perbanas Review, Vol 1 No 01 November 2015, Perbanas Institute.

Kasmir. (2010). Pengantar Manajemen Keuangan. Edisi Kedua. Jakarta

Kristina dan Leny, (2015). “ Pengaruh Struktur Modal Terhadap Kinerja Keuangan Perusahaan”. EProceeding of Management, Vol. 2 No 1 April 2015, Universitas Telkom. 
Muhammad Hajar dan R.Djoko, (2017). "Pengaruh Leverage Keuangan Terhadap Profitabilitas Pada Perusahaan Pariwisata Yang Terdaftar Di Bursa Efek Indonesia Periode 2011-2015". Diponegoro Journal Of Management, Volume 6, Nomor 4. Tahun 2017, Semarang : Universitas Diponegoro.

Nafsah dan Sri Sutra, (2015) "Analisis Struktur Modal Terhadap Kinerja Keuangan Pada Perusahaan Property dan Real Estate Yang Terdaftar Di Bei”. Jurnal Riset Akuntansi Dan Bisnis, Vol. 15 No 1 Maret 2015, Sumatera Utara: Universitas Muhammadiyah

Rambat dan Ridho, (2015). Pratikum Metode Riset Bisnis. Jakarta Selatan.

Redy Khoiranto, (2010) “ Pengaruh Struktur Modal (Dar, Der, Lder) Terhadap Roe Pada Perusahaan Manufaktur Size Besar dan Kecil Yang Listing Di BEI Tahun 2009”. Manajemen, Universitas Negeri Malang.

Sugiyono, (2016). Metode Penelitian Kuantitatif Kualitatif dan R\&D. Bandung.

Sofyan Syafri Harahap, (2010). Analisis Kritis atas Laporan Keuangan. Jakarta.

Wibowo, (2016). Manajemen Kinerja Edisi Kelima. Rajawali Pers

Yusmaniarti, Y., Hesti, S., \& Lola, P. (2019). Influence PENGARUH GOOD CORPORATE GOVERNANCE, PROFITABILITAS, DAN LEVERAGE TERHADAP NILAI PERUSAHAAN PADA PERUSAHAAN PROPERTY DAN REAL ESTATE INDONESIA. Bilancia : Jurnal IImiah Akuntansi, 3(4), 406-418.

Zaki Imadudin, dkk (2014). "Pengaruh Struktur Modal Terhadap Kinerja Perusahaan". Jurnal Wawasan Manajemen, Vol. 2 No 1 Februari 2014, Banjarmasin : Universitas Lambung Mangkurat. 
